\title{
A Study on Dimensional and Marginal Gap Changes Through Application of Different Sintering Methods and Veneer Firings on Zirconia Crowns
}

\author{
Hasan Murat Aydogdu(0000-0002-1179-8957) ${ }^{\alpha}$, Murat Eskitascioglu(0000-0002-5009-5007) ${ }^{\beta}$
}

Selcuk Dent J, 2021; 8: 522-529 (Doi: 10.15311/selcukdentj.837186)

Basvuru Tarihi: 07 Aralık 2020 Yayına Kabul Tarihi: 21 Aralık 2020

\section{ABSTRACT}

A Study on Dimensional and Marginal Gap Changes Through Application of Different Sintering Methods and Veneer Firings on Zirconia Crowns

Background: The marginal fit of dental restorations is a vital factor for long-term success. The veneering process of zirconia, which involves multiple firings at high temperatures, has shown to affect the marginal fit of zirconia cores. The aim of this study is to observe dimensional and marginal gap changes during veneer firing of zirconia frameworks sintered with different procedures.

Methods: 30 Y-TZP ((inCoris ZI, Sirona, Bensheim, Germany) crown frameworks sintered with three different durations of 8 hours, 2 hours and 10 minutes. Occlusal and buccal dimensional measurements based on reference points measured with toolmaker's microscope. Frameworks subjected to veneer firings without application of veneering material to observe the effect of firing process only. All dimensional and marginal gap measurements were repeated and after veneer firings. Data were analysed with one-way ANOVA and paired $t$ test.

Results: No significant differences observed between the sintering shrinkage of three groups. Marginal gaps decreased after veneer firings for all groups and the decrease was significant for 2 hour and 10-minute sintering groups $(p<.05)$. The occlusal surface dimensional changes were negative which indicates shrinkage; again, buccal surface was positive which indicates enlargement. No significant differences between the three groups regarding surface dimensions were detected.

Conclusion: For all three sintering groups, veneer firing caused distortion on zirconia structures in the form of shrinkage in occlusal surfaces and enlargement in buccal surfaces, whereas marginal gap values decreased after firing in all groups.

\section{KEYWORDS}

Ceramics, Dental porcelain, Dental research, Prosthodontics

Advancements in dental technology and material science have facilitated the use of different materials and production systems for all-ceramic dental restorations. ${ }^{1-3}$ There are two main configuration options for all-ceramic prosthetic restorations: a singlelayered design with a monolithic ceramic which supplies both the strength and esthetic demands; and a bilayer design with a strong but non-esthetic ceramic core that supports the weaker esthetic veneering material. A widely-used core material for the bi-layered

\section{öz}

Zirkonya Kronlarda Farklı Sinter Prosedürleri ve Veneer Pişirmeleri ile Birlikte Görülen Boyutsal ve Marjinal Aralık Değişimleri

Amaç: Dental restorasyonların marjinal uyumu, uzun vadeli başarı için hayati bir faktördür. Yüksek sıcaklıklarda birden fazla sayıda fırınlamayı içeren zirkonyum veneerleme işleminin, zirkonya altyapıların marjinal uyumunu etkilediği gösterilmiştir. Bu çalışmanın amacı, farklı prosedürlerle sinterlenmiş zirkonya iskeletlerin veneerleme pişirimleri sırasındaki boyutsal ve marjinal boşluk değişimlerini gözlemlemektir.

Gereç ve Yöntemler: 30 Y-TZP ((inCoris ZI, Sirona, Bensheim, Almanya) kuron altyapısı 8 saat, 2 saat ve 10 dakikalık üç farklı süre ile sinterlendi. Ölçüm mikroskobu ile referans noktalarına dayalı oklüzal ve bukkal boyutsal ölçümler yapıldı. Pişirme işleminin etkisini gözlemlemek için porselen malzemesi uygulanmadan veneer pişirmeleri yapıldı. Tüm boyutsal ve marjinal boşluk ölçümleri tekrarlandı ve veneer fırınlamasından önce ve sonra alınan veriler tek yönlü ANOVA ve eșleștirilmiş $t$ testi ile analiz edildi.

Bulgular: Üç grubun sinterleme büzülmesi arasında önemli bir farklılık gözlenmedi. Marjinal boşluklar tüm gruplarda veneer pişirmelerinden sonra azaldı ve azalma 2 saat ve 10 dakikalık sinterleme gruplarında anlamlıydı $(p<.05)$. Oklüzal yüzey boyutsal değişiklikleri büzülmeyi gösterecek şekilde negatifti; bukkal yüzeylerde ise genişlemeyi gösterecek şekilde pozitifti,. Yüzeylerdeki boyutsal değişim açısından üç grup arasında istetistiksel olarak anlamlı bir farklıık tespit edilmedi.

Sonuç: Her üç sinterleme grubu için de veneer pişirimi zirkonyum yapılarda okluzal yüzeylerde küçülme ve bukkal yüzeylerde genişleme şeklinde distorsiyona neden olurken, tüm gruplarda pişirme sonrası marjinal boşluk değerleri azalmıştır.

\section{ANAHTAR KELIMELER}

Dental araştırma, Dental porselen, Prostodonti, Seramikler

design is yttria-stabilized tetragonal zirconia polycrystals (Y-TZP) in the shape of pre-sintered blocks for computer-aided design and computer-aided manufacturing (CAD/CAM) techniques. The restorations milled from pre-sintered blocks are then sintered at high temperatures and finally veneered with porcelain. ${ }^{4,5}$ Additionally, in a 2007 study by Conrad et al, Y-TZP was also proposed as an excellent restorative option for the frameworks of crowns and fixed partial denture prosthesis (FPDP) restorations. $^{6}$ Overall, the

\footnotetext{
${ }^{\alpha}$ Nuh Naci Yazgan University University Faculty of Dentistry, Department of Prosthodontics, Kayseri, Turkey

${ }^{\beta}$ Yuzuncu Y1l University, Department of Prosthodontics, Van, Turkey
} 
biocompatibility and advantageous mechanical properties of Y-TZP have highlighted it as an alternative for conventional metal frameworks used in dental prostheses. ${ }^{7,8}$

The sintering of Y-TZP is a time-consuming process, and faster techniques may therefore improve the efficiency of laboratory workflow. As such, previous studies have investigated faster sintering options for soft-milled Y-TZP restorations. They showed that different sintering conditions had an effect on the grain size, phase distribution, and flexural strength of $Y$ TZP. ${ }^{9-13}$ To the best of our knowledge, the effect of sintering conditions on the dimensional stability of $Y$ TZP was not yet investigated. However, the dimensional changes and distortions relate closely with the fit of the restorations and the durability of veneering materials. In this regard Beuer et al. showed in a 2009 and 2012 study that the main failing factor of such restoration system was the occurrence of chipping of the veneering porcelain. ${ }^{2,14}$

The marginal fit of dental restorations is a vital factor for long-term success and a lack of fit would be detrimental for tooth and periodontal tissues 3, 15-18. The veneering process of zirconia, which involves multiple firings at high temperatures, has shown to affect the marginal fit of zirconia cores. ${ }^{19-23}$ In that respect the aim of this study was to investigate the effect of multiple firings during the veneering process on the marginal fit of YTZP frameworks sintered with different procedures. The null hypotheses of the current study are; there is no difference between the changes in dimensions and marginal gaps of zirconia frameworks (produced with three different sintering methods and subjected to multiple firings).

\section{MATERIALS AND METHODS}

\section{Manufacturing of the master model}

A mandibular first molar acrylic tooth model (Kawo EWL, Kavo Dental Gmbh Biberach, Germany) was prepared for a full-coverage crown. The preparation had a $1,0 \mathrm{~mm}$ wide chamfer finishing line, $6 \times 6$ degrees (12 degree tapered) axial walls, and a 1,5 mm occlusal reduction. The prepared tooth was placed in a custom-made metal mold and filled with wax to form an abutment base with 36 reference points.

A putty-wash condensation silicone impression (Optosil-Xantopren, Heraus Gmbh, Hanau, Germany) of the abutment was made to create a mold. An autopolymerizing acrylic resin (GC Pattern Resin LS, GC Europe N.V., Leuven, Belgium. Batch No. 1305234) was poured into the impression to form a castable pattern. After the polymerization, a $\mathrm{Cr}-\mathrm{Ni}$ alloy (Torr 120, Torr Dental, Istanbul, Turkey) master die was casted using the acrylic pattern.

\section{Manufacturing of the frameworks}

The master die was then digitized with a digital dental scanner (CEREC InEos Blue, Sirona, Bensheim, Germany), and the zirconia framework designed with a CAD software (CEREC InLab SW 4.2, Sirona, Bensheim, Germany) with a thickness of $0.5 \mathrm{~mm}$ as recommended by the software manufacturer.

30 identical frameworks (10 per group) were milled (InLab MCXL, Sirona, Bensheim, Germany) from first generation conventional pre-sintered Y-TZP blocks (inCoris Zl, 40/19 F1, Sirona, Bensheim, Germany. Batch No. 2010420207, composition: ZrO2-HfO2Y2O3). Then, a low speed handpiece and a $0.5 \mathrm{~mm}$ diameter tungsten bur were used to create the marking points; there were four occlusal and four buccal on each framework. These points acted as reference points for dimensional measurements. (Figure 1) Since the measurements were focused on the changes within every sample, points were marked at the approximate locations of the tubercle tips on all frameworks.

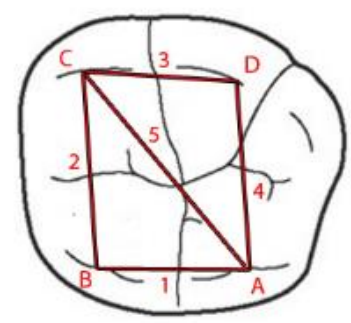

Figure 1

Schematic drawing of measured occlusal distances 1-5. A, B, C and D are the reference points (Created in Adobe Photoshop)

The milled Y-TZP frameworks were dried at $150^{\circ} \mathrm{C}$ for $10 \mathrm{~min}$ according to the manufacturer's recommendations.

Following drying; initial dimensional measurements were made on the occlusal and buccal surfaces of the frameworks as to be explained in the measurements section.

Frameworks were randomly assigned to three groups (10 samples per group) termed A, B, and C, and they were exposed to various sintering time and temperature settings. The settings used were fixed programs of the used sintering furnace (inFire HTC Speed, Sirona, Bensheim Germany). For group A, Program 5 (classic) was used, which included sintering at $1510^{\circ} \mathrm{C}$, a holding time of $120 \mathrm{~min}$, and a 
total sintering time of approximately $8 \mathrm{~h}$. For group B, Program 2 (speed) was used, which included sintering at $1540^{\circ} \mathrm{C}$, a holding time of $25 \mathrm{~min}$, and a total sintering time of approximately $2 \mathrm{~h}$. Finally, for group C, Program 1 (superspeed) was used, which required pre-heating to $1580^{\circ} \mathrm{C}$ before starting the holding time of $10 \mathrm{~min}$. After the $10 \mathrm{~min}$ holding time, samples were immediately removed, resulting in a total sintering time of $10 \mathrm{~min}$.

After cooling, thickness of all frameworks was measured directly by a precision digital caliper (Digimatic Caliper IP67, Mitutoyo, Tokyo, Japan) and verified to be as required.

\section{Measurements}

The four reference points on a measured surface formed a quadrangle, and a Toolmaker's microscope (TM-505, Mitutoyo, Tokyo, Japan) with a magnification of $60 \times$ was used to measure the five distances between them, as shown in Figure 1. The accuracy of the micrometer heads used was $3 \mu \mathrm{m}$ according to the manufacturer's data. The observer places the cross-line on the reference point, resets the micrometer, and then moves to the next reference point. The final reading on the micrometer screen was the determined distance between two reference points. Every measurement was repeated 3 times, and the average value was taken. The projection areas of the quadrangles on tooth surfaces were calculated using the distance values. (Method used for calculating the area of the quadrangle: A diagonal line (Line 5 in Figure 1) cuts the quadrangle into two triangles. Area of each triangle $(F)$ is calculated separately with the formula; (given that $\mathrm{a}, \mathrm{b}$ and $\mathrm{c}$ are the legs of the triangle) $p=(\mathrm{a}+\mathrm{b}+\mathrm{c}) / 2 ; F=$ $\sqrt{ }\left(2 \& p^{*}(p-a)^{*}(p-b) *(p-c)\right)$

Marginal assessment was done by measuring the marginal gap on the metal master die according to the criteria defined by Holmes et al. ${ }^{16} \mathrm{~A}$ custom-made device was used to position the rotating die perpendicular to the optical axis of the microscope with a pressing part to fix the framework on the die. Marginal gap measurements were performed with the Toolmaker's microscope as described above (Figure 2). Thirty-six equidistant reference points, which were marked on the master die, were used to measure the vertical marginal gap of each framework in accordance with the criteria established by Groten et al. ${ }^{24}$ (Figure 2)
Marginal assessment was done by measuring the marginal gap on the metal master die according to the criteria defined by Holmes et al. ${ }^{16}$. A custommade device was used to position the rotating die perpendicular to the optical axis of the microscope with a pressing part to fix the framework on the die. Marginal gap measurements were performed with the Toolmaker's microscope as described above (Figure 2). Thirty-six equidistant reference points, which were marked on the master die, were used to measure the vertical marginal gap of each framework in accordance with the criteria established by Groten et al. ${ }^{24}$ (Figure 2)

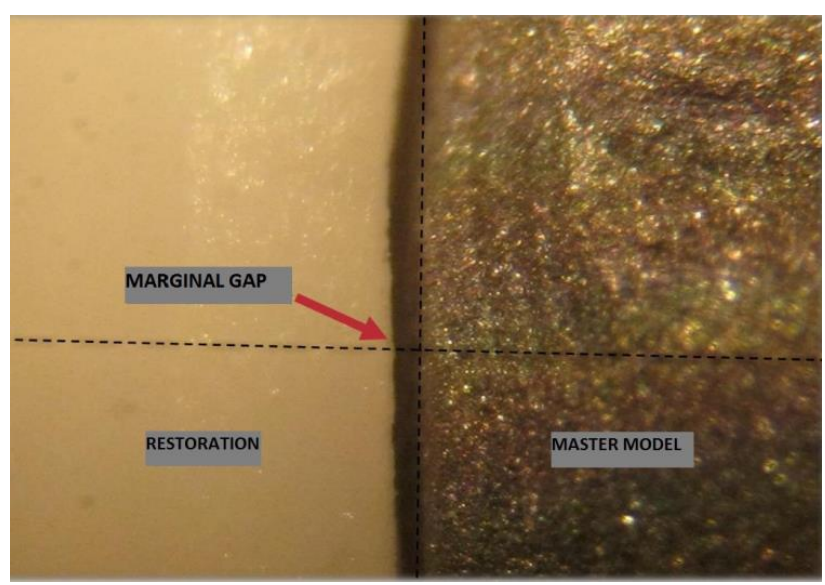

Figure 2

Microscope view of marginal gap (Texts were added in Adobe Photoshop)

To simulate the application of IPS e.max Ceram veneering porcelain (Ivoclar Vivadent, Schaan, Liechtenstein), all samples were processed through five firing stages: liner, wash, 1st dentin/incisal, 2nd dentin/incisal, and glaze. Veneer firings were performed without applying porcelain in order to examine the isolated effect of heat treatments on zirconia frameworks only. The temperature and time of all firing steps were followed according to the manufacturer's instructions. (Table 1)

Table 1.

Veneer firing steps and parameters (1-liner; 2wash; 3-1st dentin/incisal; 4-2nd dentin/incisal; 5glaze)

\begin{tabular}{|cccccccccc} 
Phase & $\begin{array}{c}\text { Stand- } \\
\text { by } \\
\text { temp. } \\
\left({ }^{\circ} \mathrm{C}\right)\end{array}$ & $\begin{array}{c}\text { Closing } \\
\text { time } \\
(\mathrm{m}: \mathrm{s})\end{array}$ & $\begin{array}{c}\text { Temp. } \\
\text { increase } \\
\left({ }^{\circ} \mathrm{C} / \mathrm{m}\right)\end{array}$ & $\begin{array}{c}\text { Holding } \\
\text { temp. } \\
\left({ }^{\circ} \mathrm{C}\right)\end{array}$ & $\begin{array}{c}\text { Holding } \\
\text { time } \\
(\mathrm{m}: \mathrm{s})\end{array}$ & $\begin{array}{c}\text { Vacuum } \\
\text { on }\left({ }^{\circ} \mathrm{C}\right)\end{array}$ & $\begin{array}{c}\text { Vacuum } \\
\text { off }\left({ }^{\circ} \mathrm{C}\right)\end{array}$ & $\begin{array}{c}\text { Long- } \\
\text { term } \\
\text { cooling } \\
\left({ }^{\circ} \mathrm{C}\right)\end{array}$ \\
\hline 1 & 403 & $4: 00$ & 40 & 960 & $1: 00$ & 450 & 959 & - \\
\hline 2 & 403 & $4: 00$ & 40 & 750 & $1: 00$ & 450 & 749 & - \\
\hline 3 & 403 & $4: 00$ & 40 & 750 & $1: 00$ & 450 & 749 & - \\
\hline 4 & 403 & $4: 00$ & 40 & 750 & $1: 00$ & 450 & 749 & - \\
\hline 5 & 403 & $6: 00$ & 60 & 725 & $1: 00$ & 450 & 724 & 450 \\
\hline
\end{tabular}


Dimensional measurements of buccal-occlusal surfaces and marginal gap measurements were repeated and double checked for all samples after veneer firings.

\section{Statistical analysis}

Statistical analysis of data was performed with SAS Version 9.3 software (SAS Institute, Cary, NC, USA). For the analysis three types of measurements were made: before sintering (BS); before veneer firings (BVF) and after veneer firings (AVF). Descriptive statistics were mean, standard deviation, and \%95 confidence interval for mean. Kolmogorov Simirnov test was used normality test. One-way analysis of variances was used for comparing groups means with Levene's and Tukey tests. To compare BVF and AVF was used paired $t$ test. Statistical significance level was 0.05 . Post power analysis of mean marginal gap data indicate that the difference in the response of matched pairs is normally distributed with standard deviation 4,4. If the true difference in the mean response of matched pairs is 3,83 , we will be able to reject the null hypothesis that this response difference is zero with probability (power) ,683. The Type I error probability associated with this test of this null hypothesis is 0,05 .

\section{RESULTS}

The sintering shrinkage of all groups were similar, accordingly the change between the BS and AVF measurements (sintering shrinkage) presented no significant difference between the three sintering groups. (Table 2)

\section{Table 2.}

Sintering shrinkage (BS-BVF) mean values with standard deviations for three sintering groups. A: 8 regular sintering; B: 2 hours speed sintering; C: 10 minutes superspeed sintering

\begin{tabular}{|c|c|c|c|c|c|c|c|}
\hline & \multirow[b]{2}{*}{ Groups } & \multirow[b]{2}{*}{$\mathrm{n}$} & \multirow[b]{2}{*}{$\begin{array}{l}\% \text { Mean } \pm \text { Std. } \\
\text { Deviation }\end{array}$} & \multicolumn{2}{|c|}{$\begin{array}{l}\text { 95\% Confidence Interval for } \\
\text { Mean }\end{array}$} & \multicolumn{2}{|c|}{ One Way ANOVA } \\
\hline & & & & Lower Bound & Upper Bound & $\mathrm{F}$ & p value \\
\hline \multirow{3}{*}{$\begin{array}{l}\text { Occlusal } \\
\text { Surface }\end{array}$} & A & 10 & $36.16 \pm 0.3$ & 35.97 & 36.35 & \multirow{3}{*}{0.036} & \multirow{3}{*}{0.964} \\
\hline & B & 10 & $36.22 \pm 0.5$ & 35.89 & 36.56 & & \\
\hline & c & 10 & $36.23 \pm 1.0$ & 35.48 & 36.98 & & \\
\hline \multirow{3}{*}{$\begin{array}{l}\text { Buccal } \\
\text { Surface }\end{array}$} & A & 10 & $36.06 \pm 0.8$ & 35.5 & 36.63 & \multirow{3}{*}{0.001} & \multirow{3}{*}{0.999} \\
\hline & B & 10 & $36.08 \pm 0.5$ & 35.73 & 36.42 & & \\
\hline & C & 10 & $36.07 \pm 0.7$ & 35.6 & 36.56 & & \\
\hline
\end{tabular}

There was no significant difference between sintering groups $\mathrm{A}, \mathrm{B}$, and $\mathrm{C}$ regarding the BVF and AVF mean marginal gap values $(p>.05)$. Conversely, the mean marginal gap values were decreased after veneer firings and AVF values were significantly lower than the $B V F$ values within group $B$ and $C$ and total $(p<.05)$. (Table 3)
Table 3.

Mean marginal gap values with standard deviations for three groups (BVF: Before Veneer firings; AVF: After Veneer Firings); A: 8 regular sintering; B: 2 hours speed sintering; C: 10 minutes superspeed sintering

\begin{tabular}{|ccccccccc|}
\hline & & $\begin{array}{c}\text { BVF } \\
\text { Measurement }\end{array}$ & $\begin{array}{c}\text { AVF } \\
\text { Measurement }\end{array}$ & \multicolumn{5}{c|}{ Differences between measurements } \\
\hline Groups & $n$ & Mean \pm SD & Mean \pm SD & Mean \pm SD & $\begin{array}{c}\text { Lover } \\
\text { Bound }\end{array}$ & $\begin{array}{c}\text { Upper } \\
\text { Bound }\end{array}$ & $\begin{array}{c}t \\
\text { value }\end{array}$ & $p$ value \\
\hline A & 10 & $48.55 \pm 15.2$ & $46.45 \pm 15.0$ & $2.10 \pm 5.3$ & -1.7 & 5.9 & 1.3 & 0.243 \\
\hline B & 10 & $43.68 \pm 10.6$ & $38.69 \pm 10.2$ & $4.99 \pm 2.8$ & 3.0 & 7.0 & 5.6 & $>0,001^{*}$ \\
\hline C & 10 & $44.19 \pm 15.3$ & $39.78 \pm 13.7$ & $4.41 \pm 4.4$ & 1.2 & 7.6 & 3.1 & $0.012^{*}$ \\
\hline $\begin{array}{c}\text { ANOVA } \\
\text { p value }\end{array}$ & 0.693 & 0.372 & 0.302 & & & & \\
\hline Total & 30 & $45.48 \pm 13.6$ & $41.64 \pm 13.1$ & $3.83 \pm 4.4$ & 2.2 & 5.5 & 4.8 & $>>001^{*}$ \\
\hline
\end{tabular}

*statistically significant $(p<.05)$

The occlusal surface area values showed a negative change for AVF, which suggested shrinkage of the framework surface. There was no significant difference between the groups regarding their occlusal surfaces $(p>.05)$. On the contrary, buccal surface area values showed a positive change and suggests enlargement of the framework surface. There was also no significant difference between the three groups regarding buccal surface $(p>.05)$. (Table 4$)$

Table 4.

Occlusal and Buccal surface area values and changes as percentages after veneer firings with standard deviations for three groups

\begin{tabular}{|c|c|c|c|c|c|c|c|c|c|}
\hline & \multirow[b]{2}{*}{ Groups } & \multirow[b]{2}{*}{$\mathrm{n}$} & \multirow{2}{*}{$\begin{array}{c}\text { BVF } \\
\text { Measurement } \\
\text { Mean } \pm \text { SD }\end{array}$} & \multirow{2}{*}{$\begin{array}{c}\text { AVF } \\
\text { Measurement } \\
\text { Mean } \pm S D\end{array}$} & \multicolumn{5}{|c|}{ Differences between measurements } \\
\hline & & & & & Mean \pm SD & $\begin{array}{l}\text { Lover } \\
\text { Bound }\end{array}$ & $\begin{array}{l}\text { Upper } \\
\text { Bound }\end{array}$ & $\begin{array}{c}\mathrm{t} \\
\text { value }\end{array}$ & $\begin{array}{c}p \\
\text { value }\end{array}$ \\
\hline \multirow{5}{*}{ Occlusal } & $8 \mathrm{~h}$ & 10 & $62.68 \pm 1.5$ & $62.57 \pm 1.475$ & $0.11 \pm 0.2$ & -0.03 & 0.25 & 1.7 & 0.118 \\
\hline & $2 \mathrm{~h}$ & 10 & $61.88 \pm 3.0$ & $61.73 \pm 3.056$ & $0.15 \pm 0.2$ & 0.02 & 0.29 & 2.5 & 0.032 \\
\hline & $10 \mathrm{~m}$ & 10 & $63.87 \pm 1.1$ & $63.79 \pm 1.168$ & $0.08 \pm 0.2$ & -0.1 & 0.28 & 1.0 & 0.342 \\
\hline & $\begin{array}{l}\text { ANOVA } \\
\text { p value }\end{array}$ & & 0.111 & 0.101 & 0.799 & & & & \\
\hline & Total & 30 & $62.81 \pm 2.1$ & $62.70 \pm 2.2$ & $0.12 \pm 0.2$ & 0.04 & 0.2 & 2.9 & 0.007 \\
\hline \multirow{5}{*}{ Buccal } & $8 \mathrm{~h}$ & 10 & $65.87 \pm 14.1$ & $66.08 \pm 14.0$ & $-0.21 \pm 0.4$ & -0.5 & 0.1 & -1.5 & 0.179 \\
\hline & $2 \mathrm{~h}$ & 10 & $59.30 \pm 8.8$ & $59.49 \pm 8.90,11$ & $-0.19 \pm 0.4$ & -0.4 & 0.06 & -1.7 & 0.119 \\
\hline & $10 \mathrm{~m}$ & 10 & $75.45 \pm 9.5$ & $75.90 \pm 9.8$ & $-0.45 \pm 0.6$ & -0.9 & 0.005 & -2.2 & 0.052 \\
\hline & $\begin{array}{l}\text { ANOVA } \\
\text { p value }\end{array}$ & & 0.011 & 0.01 & 0.429 & & & & \\
\hline & Total & 30 & $66.87 \pm 12.6$ & $67.16 \pm 12.8$ & $-0.28 \pm 0.5$ & -0.5 & -0.1 & -3.1 & 0.004 \\
\hline
\end{tabular}

\section{DISCUSSION}

In this study, the marginal gap changes caused by veneer firings and the dimensional changes in occlusal and buccal surfaces of zirconia copings which were sintered by three different sintering programs were investigated. The marginal gap is of importance because marginal fit is a key factor for long-term success of dental crowns ${ }^{25}$ and is associated with secondary caries and periodontal disease. ${ }^{17,26}$ In general, there is a consensus between various studies that a clinically acceptable marginal gap should be under $120 \mu \mathrm{m} .{ }^{27-30}$ 
Previous studies suggested no difference present of the marginal fit of zirconia copings with different sintering times. ${ }^{31,32}$ Similarly, our results also showed no difference with the marginal fit of BVF, when using different sintering conditions. Measurements of the mean marginal gap of BVF showed values that ranged from $33.28 \mu \mathrm{m}$ to $37.61 \mu \mathrm{m}$, whereas the AVF values ranged from $30.48 \mu \mathrm{m}$ to $35.98 \mu \mathrm{m}$. Considering all samples, the decrease in mean marginal gap values is statistically significant $(p<.05)$. When sintering groups were differentiated, the mean marginal gap decrease was statistically significant for the 2-hour sintering (B) and the 10-minute sintering $(C)$ groups but not for the 8hour sintering group $(A)$. The present study reveals that veneer firing may significantly influence the marginal fit of zirconia-based crowns, and that it may be related to the zirconia sintering method. Results of our study are consistent with previous studies, which report decreases in marginal gap of zirconia frameworks with veneer firings..$^{19,22,23}$ Considering that different sintering conditions have effect on properties like grain size and phase composition of zirconia ${ }^{7,10,11,14}$; it is conceivable that zirconia samples subjected to different sintering conditions may have different dimensional change behaviors under heat treatments due to their structural differences. However, the exact mechanism of this behavior is yet to be enlightened.

Considering the previous studies on the marginal fit of $\mathrm{CAD} / \mathrm{CAM}$, zirconia single-crown measurements vary depending on the system, the material, and the analysis method. ${ }^{33}$ For instance, Bindl and Mormann used the CEREC InLab system and reported a marginal gap of $43 \mu \mathrm{m}$ for In-Ceram Zirconia crowns. ${ }^{34}$ Kokubo et al. measured a marginal gap value of $42.5 \mu \mathrm{m}$ for Procera crowns. ${ }^{35}$ Martinez-Rus et al. used the CEREC InLab system and reported a $28.98 \mu \mathrm{m}$ marginal gap for InCeram Zirconia crowns and an $8.67 \mu \mathrm{m}$ gap for Procera crowns. ${ }^{36}$ Additionally, Alghazzawi et al. also used the CEREC InLab system and measured a $53 \mu \mathrm{m}$ mean marginal gap value for In-Ceram Zirconia crowns. ${ }^{37}$ Therefore, the results of our investigation regarding the marginal gap values were consistent with previous studies and within clinically acceptable range.

In the present study, veneer firings without the application of porcelain were performed to examine the isolated effect of heat treatments on the marginal gaps and dimensions of zirconia frameworks. To the best of our knowledge, there is currently only one published study that similarly investigated the effect of heat treatments with focus on as sintered zirconia. Here, Hjerppe et al. examined the effect of heat treatments on mechanical properties and reported that one or two heat treatments alone had no significant effect on the biaxial flexural strength of as-sintered zirconia disks. In contrast, applying a coating of wash and glaze on the tension side led to a significant decrease. ${ }^{38}$
However, Hjerppe et al. only investigated diskshaped zirconia and no crowns. Our measurements, including the dimensional stability, revealed that all frameworks underwent shrinkage on occlusal surfaces and enlargement on buccal surfaces, regardless of the sintering method, when subjected to heat treatments (without the application of porcelain). The regional enlargement of axial surfaces could be a possible factor for a better fit of the frameworks and thus a decrease of the marginal gap. These two phenomena may be related, and more data from three-dimensional measurements will be beneficial to acquire a better understanding.

The chipping or delaminating of veneering porcelain has been reported to be higher in zirconia-based restorations than for metal ceramics and other all-ceramic ones 39. Stated reasons for such problems include the mismatch of thermal expansion coefficient between zirconia and veneering porcelain, the surface treatments on zirconia, the strength of veneering porcelain, and the lack of adhesion between zirconia and veneering porcelain. ${ }^{40,41}$ The findings of the current study reveal that zirconia frameworks have multidirectional distortions independently of the forces caused by the addition of porcelain during veneer firings. These distortions would cause residual stresses in veneering porcelain and is a major factor for chipping and delaminating. .2,43 $^{42}$ Hence, the authors suggest that the effect of potential distortions in zirconia frameworks during veneer firings and its association with the chipping of veneering porcelain should be further investigated. Furthermore, possible causes of dimensional changes, including the structural changes in Y-TZP caused by the veneer firings, are not fully uncovered, and require further investigation.

First limitation of this study was that only one zirconia brand was used. The results may not differ for other zirconia materials with different chemical compositions. Another limitation is that all measurements were two-dimensional; however three-dimensional measurements may reveal more extensive knowledge of material behavior. 


\section{CONCLUSION}

Within the limitations of our study

1. Veneer firings were found to have a distortion effect in all tested groups: in the form of shrinkage of the occlusal surfaces and enlargement of the buccal surfaces.

2. Veneer firings also led to a decrease in the mean marginal gap values for all samples and was statistically significant for the faster groups with 2hour and 10-minute sintering programs but not for the standard group with an 8-hour program.

Acknowledgements: The Authors thank to Assistant Professor Baris Kaki for the Statistical Analysis.

Funding: This research had been supported by Scientific Research Projects Directorate of Yuzuncu Yil University with Project number 2014-SBE-D018. 


\section{REFERENCES}

1. Madfa AA, Al-Sanabani FA, Al-Qudami NH, Al-Sanabani JS, Amran AG. Use of zirconia in dentistry: An overview. Open Biomater J 2014; 5:1-9.

2. Beuer $F$, Stimmelmayr $M$, Gueth J-F, Edelhoff $D$, Naumann M. In vitro performance of full-contour zirconia single crowns. Dent Mater 2012; 28:449-56.

3. Demir N, Ozturk AN, Malkoc MA. Evaluation of the marginal fit of full ceramic crowns by the microcomputed tomography (micro-ct) technique. Eur $\mathrm{J}$ Dent 2014; 8:437-444.

4. Piconi C, Maccauro G. Zirconia as a ceramic biomaterial. Biomaterials 1999; 20:1-25.

5. Denry I, Kelly Jr. State of the art of zirconia for dental applications. Dent Mater 2008; 24:299-307.

6. Conrad $\mathrm{Hj}$, Seong $\mathrm{W}-\mathrm{J}$, Pesun $\mathrm{lj}$. Current ceramic materials and systems with clinical recommendations: a systematic review. J Prosthet Dent 2007; 98:389-404.

7. Inokoshi M, Zhang F, De Munck J, Minakuchi S, Naert I, Vleugels J, Van Meerbeek B, Vanmeensel K. Influence of sintering conditions on low-temperature degradation of dental zirconia. Dent Mater 2014; 30:669-78.

8. Bajraktarova-Valjakova E, Korunoska-Stevkovska V, Kapusevska B, Gigovski N, Bajraktarova-Misevska C, Grozdanov A. Contemporary dental ceramic materials, a review: chemical composition, physical and mechanical properties, indications for use. Maced $\mathrm{J}$ Med Sci 2018; 6:1742-1755.

9. Nakamura K, Adolfsson E, Milleding P, Kanno T, Ortengren $U$. Influence of grain size and veneer firing process on the flexural strength of zirconia ceramics. Eur J Oral Sci 2012; 120:249-54.

10.Stawarczyk B, Ozcan M, Hallmann L, Ender A, Mehl A, Hammerlet $\mathrm{CH}$. The effect of zirconia sintering temperature on flexural strength, grain size, and contrast ratio. Clin Oral Investig 2013; 17:269-74.

11.Kaizer MR, Gierthmuehlen PC, Dos Santos MB, Cava SS, Zhang Y. Speed sintering translucent zirconia for chairside one-visit dental restorations: optical, mechanical, and wear characteristics. Ceram Int 2017; 14:10999-1005.

12.Ersoy NM, Aydoğdu HM, Değirmenci BÜ, Çökük N, Sevimay M. The effects of sintering temperature and duration on the flexural strength and grain size of zirconia. Acta Biomater Odontol Scand 2015; 1:43-50.

13.Ahmed WM, Troczynski T, Mccullagh AP, Wyatt CC, Carvalho $R$. The influence of altering sintering protocols on the optical and mechanical properties of zirconia: a review. J Esthet Restor Dent 2019; 31:423-30.

14. Beuer F, Schweiger J, Eichberger M, Kappert HF, Gernet W, Edelhoff D. High-strength cad/cam-fabricated veneering material sintered to zirconia copings-a new fabrication mode for all-ceramic restorations. Dent Mater 2009; 25:121-8.

15.Valderhaug J, Heløe LA. Oral hygiene in a group of supervised patients with fixed prostheses. J Periodontol 1977; 48:221-4.
16. Holmes JR, Bayne SC, Holland GA, Sulik WD. Considerations in measurement of marginal fit. J Prosthet Dent 1989; 62:405-8.

17. Jacobs MS, Windeler AS. An investigation of dental luting cement solubility as a function of the marginal gap. J Prosthet Dent 1991; 65:43642.

18.Della Bona A, Kelly JR. The clinical success of all-ceramic restorations. J Am Dent Assoc 2008; 139:S8-S13.

19.Dittmer MP, Borchers L, Stiesch M, Kohorst P. Stresses and distortions within zirconia-fixed dental prostheses due to the veneering process. Acta Biomater 2009; 5:3231-9.

20.Pak HH, Han JS, Lee JB, Kim SH, Yang JH. Influence of porcelain veneering on the marginal fit of digident and lava cad/cam zirconia ceramic crowns. J Adv Prosthodont 2010; 2:33-8.

21. Cho S-H, Nagy WW, Goodman JT, Solomon E, Koike M. The effect of multiple firings on the marginal integrity of pressable ceramic single crowns. J Prosthet Dent 2012; 107:17-23.

22. Miura S, Inagaki R, Kasahara S, Yoda M. Fit of zirconia all-ceramic crowns with different cervical margin designs, before and after porcelain firing and glazing. Dent Mater $\mathrm{J}$ 2014; 33:484-9.

23. Bugurman BB, Turker SB. Clinical gap changes after porcelain firing cycles of zirconia fixed dentures. J Adv Prosthodont 2014; 6:177-84.

24.Groten M, Axmann D, Probster L, Weber H. Determination of the minimum number of marginal gap measurements required for practical in-vitro testing. J Prosthet Dent 2000; 83:40-9.

25. Hunter A, Hunter A. Gingival margins for crowns: a review and discussion. Part II: discrepancies and configurations. J Prosthet Dent 1990; 64:636-42.

26. Felton D, Kanoy B, Bayne SA, Wirthman G. Effect of in vivo crown margin discrepancies on periodontal health. J Prosthet Dent 1991; 65:357-64.

27.Belser $U$, Macentee M, Richter W. Fit of three porcelain-fused-to-metal marginal designs in vivo: A scanning electron microscope study. J Prosthet Dent 1985; 53:24-9.

28.Suárez MJ, Villaumbrosia $D$, González $P$, Pradíes G, Lozano JF. Comparison of the marginal fit of procera allceram crowns with two finish lines. Int J Prosthodont 2003; 16:229.

29. Mclean J. The estimation of cement film thickness by an in vivo technique. $\mathrm{Br}$ Dent $\mathrm{J}$ 1971; 131:107-11.

30.Euán R, Figueras-Álvarez $\mathrm{O}$, Cabratosa-Termes J, Oliver-Parra R. Marginal adaptation of zirconium dioxide copings: influence of the $\mathrm{cad} / \mathrm{cam}$ system and the finish line design. $J$ Prosthet Dent 2014; 112:155-62. 
31.Khaledi AAR, Vojdani M, Farzin M, Pirouzi S, Orandi S. The effect of sintering time on the marginal fit of zirconia copings. J Prosthodont 2018; 28:E285-E289.

32.Li L, Zhao C, Du Z, Qiu Y, Si W. Rapid-sintered dental zirconia for chair-side one-visit application. Int J Appl Ceram Technol 2019; 16:1830-35.

33. Abduo J, Lyons K, Swain M. Fit of zirconia fixed partial denture: a systematic review. J Oral Rehabil 2010; 11:866-76.

34.Bindl A, Mörmann W. Marginal and internal fit of allceramic cad/cam crown-copings on chamfer preparations. J Oral Rehabil 2005; 32:441-7.

35. Kokubo Y, Tsumita M, Kano T, Sakurai S, Fukushima S. Clinical marginal and internal gaps of zirconia allceramic crowns. J Prosthodont Res 2011; 55:40-3.

36. Martínez-Rus F, Suárez MJ, Rivera B, Pradíes G. Evaluation of the absolute marginal discrepancy of zirconia-based ceramic copings. J Prosthet Dent 2011; 105:108-14.

37.Alghazzawi TF, Liu PR, Essig ME. The effect of different fabrication steps on the marginal adaptation of two types of glass-infiltrated ceramic crown copings fabricated by cad/cam technology. J Prosthodontics 2012; 21:167-72.

38. Hjerppe J, Fröberg K, Lassila LVJ, Vallittu PK. The effect of heat treatment and feldspathic glazing on some mechanical properties of zirconia. Silicon 2010; 2:171-8.

39.Al-Amleh B, Lyons K, Swain M. Clinical trials in zirconia: a systematic review. J Oral Rehabil 2010; 37:641-52.

40. Fischer J, Grohmann P, Stawarczyk B. Effect of zirconia surface treatments on the shear strength of zirconia/veneering ceramic composites. Dent Mater J 2008; 27:448-54.

41. Silva NR, Sailer I, Zhang Y, Coelho PG, Guess PC, Zembic A, Kohal RJ. Performance of zirconia for dental healthcare. Materials 2010; 3:863-96.

42.Aboushelib MN, Feilzer AJ, De Jager N, Kleverlaan CJ. Prestresses in bilayered all-ceramic restorations. J Biomed Mater Res, Part B 2008; 87b:139-45.

43. Taskonak B, Mecholsky Jr JJ, Anusavice KJ. Residual stresses in bilayer dental ceramics. Biomaterials 2005; 16:3235-41.

Corresponding Author:

Hasan Murat AYDOGDU

Nuh Naci Yazgan University

Faculty of Dentistry

Department of Prosthodontics,

Kayseri, Turkey

Phone : +90 3523240050

E-mail :maydogdu@nny.edu.tr 